\title{
SERVICE INNOVATION CAPABILITY FOR ENHANCING MARKETING PERFORMANCE: AN SDL PERSPECTIVES
}

\author{
Lie HENG ${ }^{(1}{ }^{1}$, Augusty Tae FERDINAND ${ }^{\left({ }^{2}\right.}{ }^{*}$, Nur AFIFAH ${ }^{\circledR 3}{ }^{3}$, Ramadania RAMADANIA (D) 4 \\ 1, 3, ${ }^{4}$ Management Department, Tanjungpura University, Indonesia \\ ${ }^{1}$ Faculty of Economics and Business, Widya Dharma University, Pontianak, Indonesia \\ ${ }^{2}$ Management Department, Diponegoro University, Indonesia
}

Received 25 February 2020; accepted 29 April 2020

\begin{abstract}
This study was conducted to propose dan test a conceptual model for solving a research gap on the influence of customer orientation on marketing performance through a strategic bridge variable, service innovation capability, and consumer-centric strategy. We adopt the service-dominant logic as a basis for solving the research gap for its coverage on the value and service value innovation for attracting customers and as a stepping-stone for enhancing marketing performance. Data were collected from 145 service enterprises in Pontianak, West Kalimantan, Indonesia, as our samples for testing the proposed research model, using the software of AMOS-structural equation modeling. The main finding of this study is a strategic path for enhancing marketing performance through customer orientation and the capability for service value-creating.
\end{abstract}

Keywords: customer orientation, customer-centric strategy, service innovation capability, marketing performance, servicedominant logic, Indonesia.

JEL Classification: M31, D46, D83, L25.

\section{Introduction}

A study on customer orientation is still attracting marketing and management scholars in demonstrating the power of customer orientation in leveraging performance. The power of customer orientation could be seen in several ways such as enhancing service recovery performance (Choi et al., 2014; Leavy, 2005) and increasing marketing performance (Maurya et al., 2015; Ziggers \& Henseler, 2016). In the sales field, several studies such as Terho et al. (2015) described the direct influence of customer orientation on marketing performance, in particular, sales performance. Customer orientation is an input in the selling activities, indicated by among others, taking care of customers, feeling that every customer problem is essential to the company, giving individual attention to each customer (Choi et al., 2014, p. 278). Customer orientation could be seen as an activity for trying to figure out what a customer's needs are, having the customer's best interest in mind, helping to solve customer's problem, finding out what kind of products/services will be most helpful to a customer (Terho et al., 2015, pp. 19-20). So far research findings on the influence of customer orientation to marketing performance is a mixture, several studies demonstrated the positive impact of customer orientation to marketing performance (Homburg et al., 2011; Peterson \& Crittenden, 2018; Tajeddini, 2010; Terho et al., 2015). On the other side, studies also describe a non-significant direct influence of customer orientation on marketing performance, such as no impact of customer orientation to value perceived by the consumer as well as positive word of mouth (Mukerjee \& Shaikh, 2019). The study of Liu et al. (2019) demonstrated the insignificant direct influence of relational customer orientation to consumerside marketing performance in terms of repurchase intention. As such, study of Singh and Venugopal (2015) in their full model indicated a no-direct impact of customer orientation to marketing performance in terms of sales performance, except through several mediation strategy. Considering the problem on the inconsistent findings of the influence of customer oriention to marketing performance, the current study is an attempt to elucidate the possible process of transforming customer orientation to performance.

${ }^{*}$ Corresponding author. E-mail: augusty@live.undip.ac.id 
Service dominant logic is one of the main pillars in studies of marketing that views customers as co-creators of value, who collaborate with companies to integrate various resources in order to create unique values for beneficiaries (Greer et al., 2016). In the context of SDL, knowledge about customers provides inputs for providing benefits as well as solutions to customer's expectations and preferences. We adopt the service-dominant logic approach (Kuzgun \& Asugman, 2015; Vargo \& Lusch, 2017; Vargo et al., 2008) to solve the research gap between customer orientation and marketing performance for several reasons. Firstly, marketing strategy should be seen as a service and value creation as well as value delivery process which are recognized as the fundamental basis of exchange (Vargo et al., 2008), the better the value processing and delivering the higher the possibility for attracting customers as well as consumers. Secondly, a product or service should be created and delivered with a benefit for the target market. In order to be beneficial, a company should be striving to enhance its service value creation capability and service innovation capability as a medium for enhancing business performance (Nada \& Ali, 2015). Thirdly, A service value that is created and delivered to a target market should be a result of aligning of production and marketing function for optimizing the possibility of value creation for the target market (Matthyssens et al., 2015).

The purpose of this study is to propose a conceptual model on the process of bridging customer orientation and marketing performance by inserting several SDL-related concepts of service innovation capability, Customercentric strategy. The conceptual model was then tested in the service industry, including banks, hotels, and tours and travel companies, insurance companies, and universities in West Kalimantan, Indonesia.

\section{Literature review and hypothesis development}

\subsection{Customer orientation and customer-centric strategy}

The company's success is determined by how well they understand the complexity of customers' needs and wants. Customer orientation enables the company to produce products and services that are more in line with the consumers' needs. Studies on customer orientation have been done by many researchers (Homburg et al., 2011; Whelan et al., 2010; Arndt \& Karande, 2012; Javalgi et al., 2014). A customer-oriented company is always strengthening its business platform on customer satisfaction-driven strategy, customers' need-oriented, customer's need-based competitive advantage, a higher value for customer-driven strategy (Smirnova et al., 2018) and setting a customer focus strategy (Lamberti, 2013) as strategic marketing for coping with the dynamics of competition in the marketplace (Manral \& Harrigan, 2018).

Several studies on customer orientation (Rust et al., 2010; Terho et al., 2015; Wang et al., 2016) emphasized the importance of understanding the customer. The company's inability to meet the corresponding value of consumers' expectations will lead to consumers' dissatisfaction and will ultimately terminate the business connection with the company and even switch to other competitors. Customer orientation is a strategic way to understand the customer for facilitating the creation or the innovating of superior value. As studied by Andreassen et al. (2016), creating customer value is a basis for sustaining organizational performance as well as marketing performance. Capability in designing service and service value will increase the organization's capacity to accumulate and deploy service experiences for enhancing performance.

Based on our literature review, customer orientation or a customer-oriented company could be interpreted in several ways. Firstly, a customer-oriented company is a value pioneering (Leavy, 2005) to fill up the unexplored opportunity in the marketplace with a unique - differentiated value that is matching the consumer's value preference, create a kind of "blue ocean value" to make the competition irrelevant by creating a leap in value (Leavy, 2018) for customers and end-user. Secondly, A customeroriented company is considered as a value creator or value co-creator involving its customers. As emphasized by Grönroos and Svensson (2008) "when accepting value-inuse as a foundational value creation concept customers are the value creators; therefore a customer-oriented company could be understood as a hub of value creator, customers participate in value creation through the information and particularly the preferences they articulate in the process of value creation. Thirdly, a customer-oriented company is a consumer-centric initiator, based on the notion that marketing is dealing with demanding and well-informed customers and consumers (Shah et al., 2006).

As mentioned above, a consumer-oriented company is a value-pioneering unit, a value creator entity, and a consumer-centric initiator lead us to an exploration of how a customer-centric strategy is developed. The logic behind a consumer-centric strategy is that a company is a business actor that keeps its strategic routine on having the updated knowledge and information exchange with the customers. The information is then treated as a basis for creating value that is matching the customer and consumer preferences leading to a tailor-made type of service and value delivered (Outi et al., 2007). One of the directions of a consumer-centric strategy is achieving a superior customer experience (Burmann et al., 2011). As mentioned in the study of Ulaga (2018). The source for being a customer-centric company is the company's ability to provide a memorable customer experience. Therefore, customer's information, knowledge, and portfolio are needed by the company to generate a customer-centric strategy (Lamberti, 2013). A study of Burmann et al. (2011, p. 57) underlined the main drivers for a customer-centricity move is the internal commitment of the top-level management for the customer and customer-centricity knowledge for gaining customer insights, which a mentioned by marketing scholars as customer orientation (Li Sa et al., 2019; O’Dwyer \& Gilmore, 
2018; Smirnova et al., 2018). Moreover, a company that successfully adopt a customer focus strategy will gain a superior financial performance and customer retention (Grissemann et al., 2013), increasing buying intentions, improving company's positional advantage for enhancing company's competitive advantage (Bharadwaj et al., 2012). A case study of Ross $(2009$, p. 453) is so provoking that "manufacturers stand at the consumer centricity crossroads. The choices are lead, follow, or get out of the way. Choose lead..." with ample evidence of no less than 80 percent of high performing manufacturers who emphasize the consumer centricity move. Therefore, the following two hypotheses are proposed:

H1: Customer orientation has a positive effect on the customer-centric strategy.

H2: Customer-centric strategy has a positive effect on marketing performance.

\subsection{Customer orientation, service innovation capability, and marketing performance}

One of the provoking adagios in marketing practices in the term of "a customer is a King." Customer is the reason a company exists. The sustainability of a company's performance is not only influenced by how it anticipates the competitors' strategies but also on how a company maintains its customer knowledge as a basis for enhancing capability to offer value for attracting new customers, keeping and maintaining the current customers (Fan \& $\mathrm{Ku}, 2010)$. In service industries, a customer could be considered as co-producer (Tax et al., 2013). Hence, the company should win its customer's hearts with a specific value for goods and services they deliver into the market place. As mentioned by Naidoo (2010), a company's core concern is focusing its ability to respond to customers as well as its competitors.

As the competition the market place is increasingly dynamic, focus on innovation, in particular, service value innovation (Nada \& Ali, 2015) for provoking disequilibrium in the market place is a pivotal choice for maintaining the marketing performance (Shelby \& Caroline, 2004). Innovation, such as innovation of products and services, processes, and systems (Racela, 2014), is the key to providing and renewing the value offered to the customers as well as the consumers. Service innovation processes and capability are increasingly recognized as an effective solution to improve and maintain company growth and profitability (Tajeddini, 2010). Service innovation capability is considered as a strategic path for value creation and value-enhancing for a customer. As described in the study of Durst et al. (2015, p. 66), a service innovation capability may comprise of innovating new services in the market, initiating a new approach in involving customers in the service production, new ways in service delivery, and new ways in using technology for increasing efficiency. Service innovation capability may be realized as the capability for innovating services through technology development as well as technology utilization (Nasution et al., 2011).
The innovation service can be improved and developed with the help of new technology by integrating it based on the demands of the market. Wang and Hsu (2014) said that service innovation and technology would be able to fix and improve the products and services of the company, either in the form of tangible and intangible assets to be better. It would be possible as a result of the increasing development of services and the development of sophisticated new technologies. Additionally, product development is getting better, as well as the improvement in the service delivery system (Wang \& Hsu, 2014). Service innovation is the company's capital in overcoming a variety of very diverse customer demands. Service innovation is the solution to the company to overcome the dilemma due to the increasing competition conditions and the decline in sales and profits.

As studied by Jiménez-Zarco et al. (2011), one path to provide value for customers is the possession of a portfolio of customer knowledge; furthermore, Naidoo (2010) accentuated the better understanding of the customer as well as the consumer compared to those of a competitor is a determinant for a superior company's performance. As mentioned at the above section, a customer-oriented company is a value pioneering unit (Leavy, 2018) for its capability in pooling customer knowledge and information, and as a value creator or value co-creator (Grönroos \& Svensson, 2008) for its capability in finding ways to innovate based on the portfolio of knowledge and information from its customer as well as consumer, as a way for finding ways for enhancing the capability for service innovation capability (Jian \& Zhou, 2015; Wang et al., 2016). Therefore, the following hypotheses are proposed:

H3: Customer orientation has a positive effect on service innovation capability.

H4: Service innovation capability has a positive effect on marketing performance.

The insertion of service innovation capability as our proposed solution for bridging the gap between customer orientation and marketing performance is based on several reasons. Firstly, customer orientation as proved in many studies (Choi et al., 2014; Liu \& Lee, 2019; Matthyssens et al., 2015; Terho et al., 2015) is to so extent still inconsistent for positive impact and non-significant impact, therefore, finding out a bridging variable is a necessity. Secondly, as customer orientation as emphasized by Grönroos and Svensson (2008) could be understood as a hub of value creators due to its ability in collecting information and preferences from customers, this stock of knowledge and information could be a leverage for enhancing the service innovation capability as proposed in our hypothesis number two. The service innovation capability is proved in previous studies as a tool for enhancing marketing performance (Durst et al., 2015; Szymańska et al., 2017; Tang et al., 2013; Wegner et al., 2017) therefore a mediation process is proposed as follows:

H5: Service innovation capability mediates the influence of customer orientation on marketing performance. 


\subsection{Service innovation capability and customer- centric strategy}

Customer centricity could be defined as a kind of business practices in getting and processing consumer's knowledge and information, involving the customer in marketing and innovation process actively, and focusing on products' and services' value to increase customer experience regularly (Gebauer et al., 2011; Lamberti, 2013) as a tool for enhancing competitive advantage. When a customer-centric strategy is initiated, one point to be directed is among others emphasizing the customer intimacy (Antikainen et al., 2010), as a way for transforming the consumer's wants to be a specific value for customers (Lamberti, 2013). The capability for transforming wants to value is what we define as service innovation capability. As mentioned in several studies, a service innovation capability is an ability to deploy resources for renewing service attributes, improving qualified services, capability for improving services through IT (Nasution et al., 2011). Service innovation capability could be seen as continually searching for new ways to serve the customers better, ability to change/modify the current service approaches to meet every single special requirement from customers, and ability to come up with new service offerings compared to competitors (Grawe et al., 2009). Lending the study of Scheinbaum and Wang (2018) a customer-centric strategy is a strategy that is focusing service to the customer as a mission of the company, customer-friendly approach as a business routine, providing service as needed by customer (Scheinbaum \& Wang, 2018) as a result of ability for innovating services regularly. Therefore the following hypothesis is proposed.

H6: Service innovation capability has a positive effect on the customer-centric strategy.

\section{Method}

\subsection{Sample and data collection}

In order to test our model, we invited business managers of the small and medium service companies to participate in our research based on a convenience sample voluntarily. The respondent was the manager of the SME, assuming that a manager is the right representative of a company. A convenience sampling is adopted because of its capability to invite respondents who voluntarily participated in this research. The sampling frame is drawn from a population size of 316 service organizations, compiled from The Indonesian Financial Service Authority (abbreviated in Bahasa Indonesia as OJK), The Indonesian Hotel\&Restaurant Association (abbreviated as PHRI), Association of The Indonesian Tours and Travel Agencies (abbreviated as ASITA) and, Indonesian Institute for Higher Education Service (abbreviated as LLDIKTI). As presented in Table 1.

They were selected as our respondents for several reasons. First, although they were struggling, they
Table 1. Sampling frame

(source: compiled from several sources)

\begin{tabular}{|l|c|c|c|c|}
\hline Type of business & $\begin{array}{c}\text { Popu- } \\
\text { lation }\end{array}$ & Sample & $\begin{array}{c}\text { Proportion } \\
\text { of popu- } \\
\text { lation }\end{array}$ & $\begin{array}{c}\text { Proportion } \\
\text { of sample }\end{array}$ \\
\hline Hotel & 53 & 45 & $85 \%$ & $31.03 \%$ \\
\hline Tour and Travel & 92 & 35 & $38 \%$ & $24.14 \%$ \\
\hline Bank & 48 & 35 & $73 \%$ & $24.14 \%$ \\
\hline Insurance & 74 & 15 & $20 \%$ & $10.34 \%$ \\
\hline Education Institue & 49 & 15 & $31 \%$ & $10.34 \%$ \\
\hline Total & 316 & 145 & $45.88 \%$ & $100 \%$ \\
\hline
\end{tabular}

successfully stayed in the marketplace during the economic crisis period in Indonesia. Second, they were working in a competitive market area and still stayed in the market, demonstrating their capability in providing value to their consumers.

\subsection{Measurement of variables}

Measures used in this study were adopted and adapted from several studies, as published in a referral journal. Customer orientation measure was adapted from the study of Tajeddini (2010) and Jiménez-Zarco et al. (2011). The customer-centric strategy was measured based on the study Gebauer et al. (2011; Shah et al., 2006). The service innovation capability was measured by adapting the measurement used by Nasution et al. (2011). The marketing performance was measured by the scale used in the study of Sugiyarti et al. (2018) and Limakrisna and Yoserizal (2016) The measures were then developed as a series of scale in a questionnaire set with score-point from 1 to 5 and were used as the guideline for interviewing respondents based on convenience sampling; finally, the data were collected from 145 managers of SMEs in the service industry.

\section{Data analysis}

In the early stage of this research, empirical studies were conducted by the process of testing hypotheses based on the input data obtained through a survey and with the help of Structural Equation Modeling (SEM) with AMOS version 23.0 to obtain empirical results. We selected the structural equation model in testing our model and hypotheses for several reasons. Firstly, compared to the ordinary regression analysis, Structural equation modeling works with several equations simultaneously. The same variable may represent a predictor (regressor) in one equation and a criterion (regressand) in another equation (Kroehne et al., 2003), as in our model. Secondly, the advantage of using SEM in the analysis is for the ability to testing the mediational process in a simultaneous way (Tabachnick \& Fidell, 2012).

To test our model, we ran a two-step procedure in SEM Analysis for confirmatory factor analysis for 
Table 2. Measurement of convergent validity, construct reliability

\begin{tabular}{|c|c|c|c|c|c|}
\hline Variable \& indicator & Reference & $\begin{array}{l}\text { (Lambda } \\
\text { value) }\end{array}$ & $\begin{array}{l}\text { Critical ratio } \\
\geq \pm 1.96\end{array}$ & $\begin{array}{l}\text { Convergent } \\
\text { validity (ave) } \\
\geq 0.50\end{array}$ & $\begin{array}{c}\text { Construct } \\
\text { reliability (cri) } \\
\geq 0.70\end{array}$ \\
\hline CUSTOMER ORIENTATION & \multirow{4}{*}{$\begin{array}{l}\text { Tajeddini } \\
\text { (2010), Jiménez- } \\
\text { Zarco et al. } \\
(2011)\end{array}$} & & & 0,618 & 0,827 \\
\hline - Understanding market trend & & 0.718 & 9.242 & & \\
\hline - Customer preference information seeking & & 0.699 & 8.955 & & \\
\hline - Value oriented effort for customer & & 0.922 & 8.955 & & \\
\hline CUSTOMER CENTRIC STRATEGY & \multirow{4}{*}{$\begin{array}{l}\text { Shah et al. } \\
\text { (2006) Gebauer } \\
\text { et al. (2011) }\end{array}$} & & & 0.536 & 0.774 \\
\hline - Driving for customer satisfaction & & 0.616 & 7.275 & & \\
\hline $\begin{array}{l}\text { - Laverage value through customer } \\
\text { relationship }\end{array}$ & & 0.832 & 7.275 & & \\
\hline - Company priority is customer satisfaction & & 0.733 & 6.939 & & \\
\hline SERVICE INNOVATION CAPABILITY & \multirow{4}{*}{$\begin{array}{l}\text { Nasution et al. } \\
(2011)\end{array}$} & & & 0.562 & 0.789 \\
\hline - Capability for innovating services & & 0.658 & 6.615 & & \\
\hline $\begin{array}{l}\text { - Capability for improving services through } \\
\text { qualified service }\end{array}$ & & 0.912 & 7.462 & & \\
\hline - Capability for improving services through IT & & 0.648 & 7.462 & & \\
\hline MARKETING PERFORMANCE & \multirow{4}{*}{$\begin{array}{l}\text { Sugiyarti } \\
\text { et al. (2018), } \\
\text { Limakrisna and } \\
\text { Yoserizal (2016) }\end{array}$} & & & 0.696 & 0.867 \\
\hline - Sales growth & & 0.912 & 5.907 & & \\
\hline - Customer growth & & 0.555 & 5.907 & & \\
\hline - Scope of market coverage & & 0.974 & 5.701 & & \\
\hline
\end{tabular}

measuring the construct and a full structural model for testing the hypothesis. The first step in data analysis is running a confirmatory factor analysis for exogenous constructs in the model, followed by the endogenous constructs. As appeared in the model, the exogenous construct is only one variable of customer orientation with three indicators, while the endogenous construct comprises three constructs of customer-centric strategy, service innovation capability, and marketing performance. The confirmatory factor analysis resulted in an adequacy measurement of the construct, and the convergent validity, construct reliability as presented in the following Table 2 .

The confirmatory factor analysis resulted in an acceptable loading factor for every variable in the model. All loading factors are exceeding the minimum expected value of $\geq 0.50$, with a critical ratio of $\geq 1.96$ (Arbuckle, 2016; Tabachnick \& Fidell, 2012), which indicates that the magnitude of each indicator's contribution to the constructed variables is significant at five percent. In total, all constructs demonstrate acceptable measurements. Construct validity was measured by AVE (average variance extracted), with a minimum level of $\geq 0.50$. The analysis resulted in a level of accepted convergence validity, such as 0.618 for customer orientation, 0.536 for customer centricity, 0.562 for service innovation capability, and 0.696 for marketing performance.

We continue to analyze the construct-reliability of the latent variable in the model. All of the construct variables have acceptable construct reliability, such as the customer orientation (0.827), the customer-centric strategy (0.774), the service innovation capability (0.789), and the marketing performance (0.867) above the cut-off value of $\geq 0.70$ (Arbuckle, 2016; Tabachnick \& Fidell, 2012).

The second step of analysis is running a full structural equation modeling. Full SEM analysis was conducted to test the possibility of accepting the model as well as the hypotheses; the result is presented in Figure 1, with a summary of the hypotheses testing results in Table 3.

As shown in Table 3, our proposed model is well-supported, with good GFI (0.916), good CFI (0.953), good TLI (0.937), and good RMSEA (0.075). All our proposed hypotheses are supported with a critical ratio $>1.96$ with a significant level below 0.05 , except hypothesis of the influence of customer-centric strategy to marketing performance is not significant; therefore, the conclusion is rejected.

\section{Mediation effect of service innovation capability}

As explored in the introduction section of the current research, a gap in the literature on the inconsistency of customer orientation impact on marketing performance leads us to inset a mediation variable of service innovation capability, as stated in hypothesis number 3. In order to test the mediation effect, we adopt the procedure of Baron and Kenny (1986) and conducted four procedures for testing the mediation. The first process was running the regression for the independent variable to the dependent variable and resulted in a significant unstandardized regression weight $=0.217$ with Critical Ratio $=2.2165$. The second process is running the regression for the independent variable to the mediation variable, resulting in a significant unstandardized regression weight of 0.436 with 


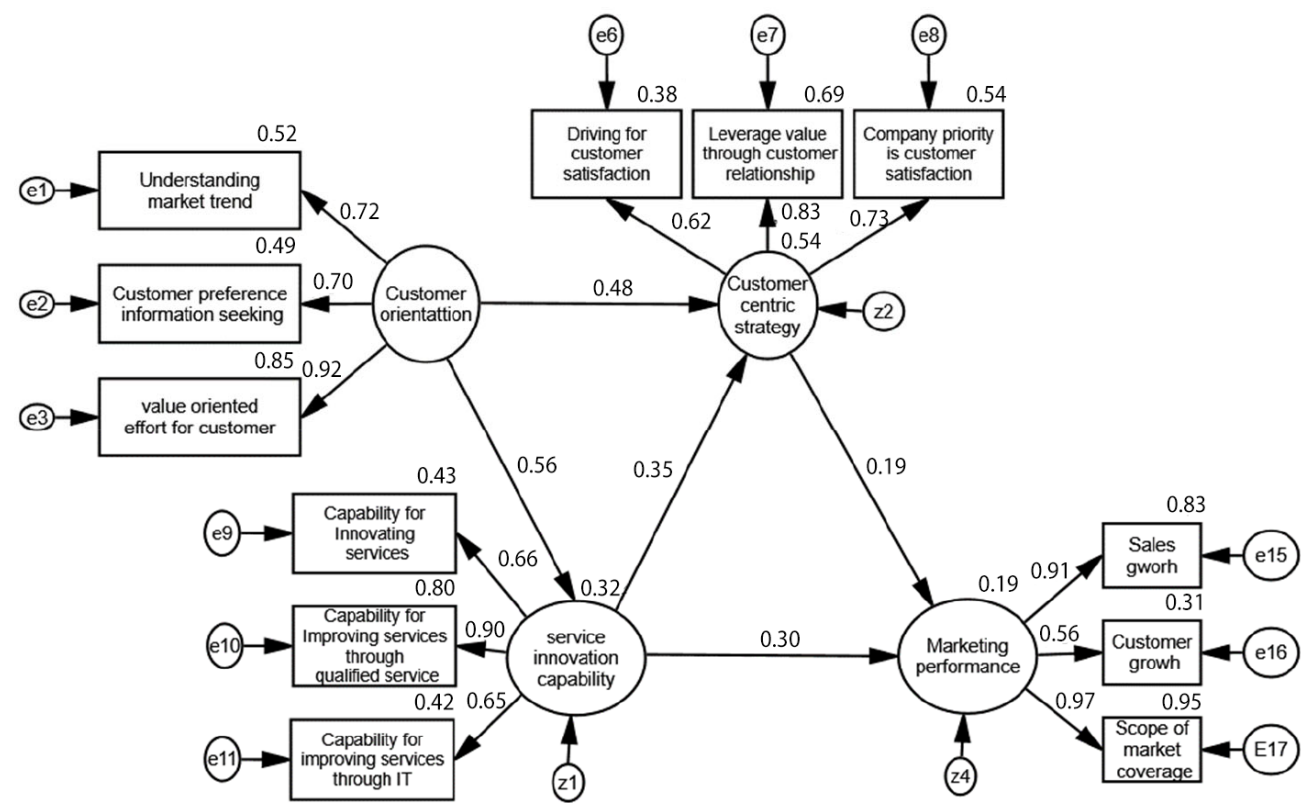

Model testing: Chi square $=88.245 ;$ Significance $=0.000 ; \mathrm{GFI}=0.916 ; \mathrm{TLI}=0.937 ; \mathrm{CFI}=0.953 ;$ RMSEA $=0.075$

Figure 1. Full structural model

Table 3. Hypothesis testing criteria

\begin{tabular}{|c|c|c|c|c|c|c|}
\hline \multirow{2}{*}{ The hypothesized relationship } & Std. & \multirow{2}{*}{ Estimate } & \multirow{2}{*}{ S.E. } & \multirow{2}{*}{ C.R. } & \multirow{2}{*}{$\mathrm{P}$} & \multirow[t]{2}{*}{ Conclusion } \\
\hline & Estimate & & & & & \\
\hline H1: Customer orientation $\rightarrow$ Customer centric strategy & 0.482 & 0.339 & 0.083 & 4.062 & $* * *$ & Accepted \\
\hline H2: Customer centric strategy $\rightarrow$ Marketing performance & 0.190 & 0.291 & 0.190 & 1.529 & 0.126 & Rejected \\
\hline H3: Customer orientation $\rightarrow$ Service innovation capability & 0.562 & 0.463 & 0.090 & 5.150 & $* * *$ & Accepted \\
\hline H4: Service innovation capability $\rightarrow$ Marketing performance & 0.295 & 0.385 & 0.190 & 2.374 & 0.018 & Accepted \\
\hline $\begin{array}{l}\text { H5: Service innovation capability mediates the influence of } \\
\text { customer orientation on marketing performance }\end{array}$ & \multicolumn{6}{|c|}{$\begin{array}{l}\text { Full mediation is confirmed and significant } \\
\text { (Baron and Kenny procedure (1986) }\end{array}$} \\
\hline - P1: Independent Variable (IV) $\rightarrow$ Dependent Variable (DV) & 0.200 & 0.217 & 0.098 & 2.616 & 0.027 & Significant \\
\hline - P2: IV $\rightarrow$ Mediation Variable (MV) & 0.559 & 0.436 & 0.089 & 4.894 & $* * *$ & Significant \\
\hline$-\mathrm{P} 3: \mathrm{MV} \rightarrow \mathrm{DV}$ & 0.446 & 0.564 & 0.128 & 4.400 & $* * *$ & Significant \\
\hline - P4: Independent $\rightarrow$ Dependent & \multirow[b]{2}{*}{-0.041} & \multirow[b]{2}{*}{-0.043} & \multirow[b]{2}{*}{0.116} & \multirow[b]{2}{*}{0.371} & \multirow[b]{2}{*}{0.710} & \multirow[b]{2}{*}{$\begin{array}{l}\text { Not } \\
\text { Significant }\end{array}$} \\
\hline $\begin{array}{l}\text { - Influence of Customer orientation on Marketing performance } \\
\text { becomes insignificant, and the magnitude of effect reduces } \\
\text { when the mediation variable is inserted in the model }\end{array}$ & & & & & & \\
\hline H6: Service innovation capability $\rightarrow$ Customer centric strategy & 0.348 & 0.297 & 0.098 & 3.020 & 0.002 & Accepted \\
\hline Goodness of Fit Test & & & \multicolumn{2}{|c|}{ Cut-off Value } & Result & Conclusion \\
\hline Chi-square & & & \multicolumn{2}{|c|}{ Small } & 88.245 & Not Fit \\
\hline Significance & & & \multicolumn{2}{|c|}{$\geq 0.05$} & 0.000 & Not Fit \\
\hline Goodness Fix Index & & & \multicolumn{2}{|c|}{$\geq 0.90$} & 0.916 & Fit \\
\hline Comparative Fix Index & & & \multicolumn{2}{|c|}{$\geq 0.90$} & 0.953 & Fit \\
\hline Tucker Lewis Index & & & \multicolumn{2}{|c|}{$\geq 0.90$} & 0.937 & Fit \\
\hline RMSEA - Root mean square error of approximation & & & \multicolumn{2}{|c|}{$0.03-0.08$} & 0.075 & Fit \\
\hline
\end{tabular}


Critical Ratio $=4.894$. The third process was running the regression for the mediation variable to the dependent variable and resulted in the significant unstandardized regression weigh $=0.564$ with Critical Ratio $=4.400$. The last process is running by inserted the mediation variable to the variable independent and dependent from procedure number 1 , resulted in decreasing magnitude of the unstandardized regression weight from 0.217 to be -0.043 with a Critical Ratio of 0.371 becoming not significant. The not-significant regression weight at the fourth process indicated the existence of full mediation effect of service innovation capability to the influence of customer orientation on marketing performance, as expected. The summary of those four processes is inserted in the middle of table 3 for hypothesis number 4 .

\section{Research contribution and direction for further research}

\subsection{Research contribution to the body of service knowledge}

Our primary research problem is how to elucidate the possible process of managing customer orientation to enhance marketing performance through our proposed conceptual model comprising five regressional hypotheses and a mediation hypothesis. Our hypothesis testing resulted in the acceptance of four regressional hypotheses and rejection of one hypothesis on the influence of consumer-centric strategy on marketing performance. The hypothesis of the mediation effect of service innovation capability is accepted. Based on the regression weight of our structural equation model, several finding is presented in the following passage.

Firstly, a very strategic path for enhancing marketing performance is empowering customer orientation for enhancing the service innovation capability, as a stepping stone for enhancing marketing performance. This solutive path, as proved by the acceptance of the mediation hypothesis, demonstrated the importance of customer orientation as a basis for building a stock of knowledge and information for strengthening the company's value-creator (Grönroos \& Svensson, 2008) in the form of service innovation capability. This finding is strengthening the essence of service-dominant logic that a company that maintains and empower its capability to create value, as well as cocreated value through the collecting of customer's information, will enjoy the higher marketing performance (Vargo \& Lusch, 2017; Vargo et al., 2008).

Secondly, our study proved a path for enhancing customer-centric strategy though the basis for co-creation process as mentioned as the core of service-dominant logic (Galvagno \& Dalli, 2014; Kuppelwieser \& Finsterwalder, 2016; Vargo \& Lusch, 2017; Vargo et al., 2008) in the sense of building a hub of value creator through the close relationship with customers and consumers. As customer orientation is understood as a stepping stone for value pioneering (Leavy, 2005) and value creator for consumer, company that accentuate effort to enhance the consumerbased strategy as known as a consumer-centric strategy will be focusing on products' and services' value (Gebauer et al., 2011; Lamberti, 2013) through the empowering its service innovation capability. Innovative services as the evidence of the working of a service innovation capability are the tools for empowering a consumer-centric strategy.

Thirdly, the rejection of our hypothesis on the influence of a consumer-centric strategy to marketing performance is a blessing in disguise for enriching the body of knowledge of service-dominant logic. As mentioned in the study of Scheinbaum and Wang (2018), a consumercentric culture of doing business will be empowering the customer's commitment to enhancing performance. However, the rejection of this hypothesis provides an alternative point of view that the consumer-centricity strategy only an initial way that will enhance marketing performance indirectly. Therefore, another point of search for further marketing knowledge exploration is finding any conceptual bridge variable for impacting the marketing performance.

\subsection{Managerial implication}

Based on the magnitude of our regression coefficient and the marketing strategy path drawn for the model, several managerial implications could be discussed a follows. The first implication is that service innovation capability is a reliable instrument for enhancing marketing performance.

If a company is striving to enhance the marketing performance, a pivotal point to be emphasized is the empowering or enhancement of the service innovation capability. The enhancement process may include renewing or reconfiguring the features of services to be offered into the marketplace. By improving those efforts, the company's services could be perceived as a quality-oriented service. As technology becoming part of our daily life, the application of technology as well as information technology should be a part of company service innovation effort.

The second implication, when a company is struggling for maintaining and or enhancing performance in a competitive market, initiating a synergizing relationship as a kind of customer-oriented business practices is crucial as a way to get ways for an excellent consumer-centric strategy. The insignificant effect of consumer-centric strategy on marketing performance leads us to be aware of finding on a kind process on how to manage a consumer-centric strategy to be able to enhance marketing performance. The alternative process might be such as developing any kind of service value accentuation or value resonating program, which could be considered as a way for empowering the consumer-centric strategy in enhancing marketing performance.

\section{Limitation and venue for further research}

The process of data collecting in this research is in the scope of companies' management points of view; it was 
the lack of employee's opinions. Therefore, a research venue could be directed to apply a dyadic process of data collecting to get a more precise measurement. The current study has resulted in an unexpected result on the rejection of a hypothesis on the influence of consumer-centric strategy on marketing performance. The rejection of this hypothesis provides ways for inserting a mediation between consumercentric strategy to marketing performance or a venue for reconfiguring the content of consumer-centric strategy from another perspective, such as from the perspective of self-congruence theory or social identity theory.

\section{Acknowledgements}

Special acknowledgment is extended to our respondents: leaders, managers, supervisors in the services sector industries, Pontianak, West Kalimantan, Indonesia, who had participated in the research. Special thanks to Maria Immaculata Prettyfernandy, a former staff of the Thompson Reuters Manila- Philippine Office, who translated the first draft of this article to formal English for academic purposes.

\section{Disclosure statement}

The Authors do not have any conflict of interest in all processes or writing this manuscript.

\section{References}

Andreassen, T. W., Kristensson, P., Lervik-Olsen, L., Parasuraman, A., McColl-Kennedy, J. R., Edvardsson, B., \& Colurcio, M. (2016). Linking service design to value creation and service research. Journal of Service Management, 27(1), 2129. https://doi.org/10.1108/JOSM-04-2015-0123

Antikainen, M., Mäkipää, M., \& Ahonen, M. (2010). Motivating and supporting collaboration in open innovation. European Journal of Innovation Management, 13(1), 100-119. https://doi.org/10.1108/14601061011013258

Arbuckle, J. L. (2016). IBM ${ }^{\circledast}$ SPSS $^{\circledast}$ Amos $^{\text {TN }}$ User's Guide.

Arndt, A. D., \& Karande, K. (2012). Is it better for salespeople to have the highest customer orientation or a strong fit with their group's customer orientation? Findings from automobile dealerships. Journal of Retailing and Consumer Services, 19(3), 353-359. https://doi.org/10.1016/j.jretconser.2012.03.009

Baron, R., \& Kenny, D. (1986). The moderator-mediator variable distinction in social psychological research: conceptual, strategic, and statistical considerations. Journal of Personality and Social Psychology, 51(6).

https://doi.org/10.1037/0022-3514.51.6.1173

Bharadwaj, N., Nevin, J. R., \& Wallman, J. P. (2012). Explicating hearing the voice of the customer as a manifestation of customer focus and assessing its consequences. Journal of Product Innovation Management, 29(6), 1012-1030. https://doi.org/10.1111/j.1540-5885.2012.00954.x

Burmann, C., Meurer, J., \& Kanitz, C. (2011). Customer centricity as a key to success for pharma. Journal of Medical Marketing, 11(1), 49-59. https://doi.org/10.1057/jmm.2010.30

Choi, C. H., Kim, T., Lee, G., \& Lee, S. K. (2014). Testing the stressor-strain-outcome model of customer-related social stressors in predicting emotional exhaustion, customer ori- entation and service recovery performance. International Journal of Hospitality Management, 36, 272-285.

https://doi.org/10.1016/j.ijhm.2012.09.009

Durst, S., Mention, A.-L., \& Poutanen, P. (2015). Service innovation and its impact: What do we know about? Investigaciones Europeas de Dirección y Economía de la Empresa, 21(2), 6572. https://doi.org/10.1016/j.iedee.2014.07.003

Fan, Y.-W., \& Ku, E. (2010). Customer focus, service process fit and customer relationship management profitability: the effect of knowledge sharing. The Service Industries Journal, 30(2), 203-223. https://doi.org/10.1080/02642060802120141

Galvagno, M., \& Dalli, D. (2014). Theory of value co-creation: a systematic literature review. Managing Service Quality: An International Journal, 24(6), 643-683. https://doi.org/10.1108/MSQ-09-2013-0187

Gebauer, H., Gustafsson, A., \& Witell, L. (2011). Competitive advantage through service differentiation by manufacturing companies. Journal of Business Research, 64(12), 1270-1280. https://doi.org/10.1016/j.jbusres.2011.01.015

Grawe, S. J., Chen, H., \& Daugherty, P. J. (2009). The relationship between strategic orientation, service innovation, and performance. International Journal of Physical Distribution \& Logistics Management, 39(4), 282-300. https://doi.org/10.1108/09600030910962249

Greer, C. R., Lusch, R. F., \& Vargo, S. L. (2016). A service perspective. Organizational Dynamics, 45(1), 28-38. https://doi. org/10.1016/j.orgdyn.2015.12.004

Grissemann, U., Plank, A., \& Brunner-Sperdin, A. (2013). Enhancing business performance of hotels: The role of innovation and customer orientation. International Journal of Hospitality Management, 33, 347-356.

https://doi.org/10.1016/j.ijhm.2012.10.005

Grönroos, C., \& Svensson, G. (2008). Service logic revisited: who creates value? And who co-creates? European Business Review, 20(4), 298-314. https://doi.org/10.1108/09555340810886585

Homburg, C., Müller, M., \& Klarmann, M. (2011). When does salespeople's customer orientation lead to customer loyalty? The differential effects of relational and functional customer orientation. Journal of the Academy of Marketing Science, 39(6), 795-812. https://doi.org/10.1007/s11747-010-0220-7

Javalgi, R. G., Hall, K. D., \& Cavusgil, S. T. (2014). Corporate entrepreneurship, customer-oriented selling, absorptive capacity, and international sales performance in the international B2B setting: Conceptual framework and research propositions. International Business Review. https://doi.org/10.1016/j.ibusrev.2014.04.003

Jian, Z., \& Zhou, Y. (2015). The impacts of corporate social capital and market orientation on service innovation performance: mediating role of organizational learning. LISS 2014 (pp. 1427-1431). Springer. https://doi.org/10.1007/978-3-662-43871-8_206

Jiménez-Zarco, A. I., Martínez-Ruiz, M. P., \& Izquierdo-Yusta, A. (2011). Key service innovation drivers in the tourism sector: empirical evidence and managerial implications. Service Business, 5(4), 339-360. https://doi.org/10.1007/s11628-011-0118-6

Kroehne, U., Funke, F., \& Steyer, R. (2003). (Why) Should we use SEM? - Pros and cons of Structural Equation Modelling. MPR-online, 8.

Kuppelwieser, V. G., \& Finsterwalder, J. (2016). Transformative service research and service dominant logic: Quo Vaditis? Journal of Retailing and Consumer Services, 28, 91-98. https://doi.org/10.1016/j.jretconser.2015.08.011 
Kuzgun, E., \& Asugman, G. (2015). Value in services - a service dominant logic perspective. Procedia - Social and Behavioral Sciences, 207, 242-251.

https://doi.org/10.1016/j.sbspro.2015.10.093

Lamberti, L. (2013). Customer centricity: the construct and the operational antecedents. Journal of Strategic Marketing, 21(7), 588-612. https://doi.org/10.1080/0965254X.2013.817476

Leavy, B. (2005). Value pioneering - how to discover your own "blue ocean": interview with W. Chan Kim and Renée Mauborgne. Strategy \& Leadership, 33(6), 13-20. https://doi.org/10.1108/10878570510631611

Leavy, B. (2018). Value innovation and how to successfully incubate "blue ocean" initiatives. Strategy \& Leadership, 46(3), 10-20. https://doi.org/10.1108/SL-02-2018-0020

Li Sa, M. L., Choon-Yin, S., Chai, Y. K., \& Aik Joo, J. H. (2019). Knowledge creation process, customer orientation and firm performance: Evidence from small hotels in Malaysia. Asia Pacific Management Review, 25(2), 65-74. https://doi.org/10.1016/j.apmrv.2019.07.002

Limakrisna, N., \& Yoserizal, S. (2016). Determinants of marketing performance: empirical study at National Commercial Bank in Jakarta Indonesia. Springerplus, 5(1), 1693. https://doi.org/10.1186/s40064-016-3362-3

Liu, C.-H. S., \& Lee, T. (2019). The multilevel effects of transformational leadership on entrepreneurial orientation and service innovation. International Journal of Hospitality Management, 82, 278-286. https://doi.org/10.1016/j.ijhm.2018.10.006

Liu, Y., Li, X., \& Dong Maggie, C. (2019). The role of customer orientation in key account managers' performance: a client network perspective. Journal of Business \&amp; Industrial Marketing, 34(7), 1592-1605.

https://doi.org/10.1108/JBIM-09-2017-0229

Manral, L., \& Harrigan, K. R. (2018). Corporate advantage in customer-centric diversification. Journal of Strategic Marketing, 26(6), 498-519.

https://doi.org/10.1080/0965254X.2017.1299789

Matthyssens, P., Bocconcelli, R., Pagano, A., \& Quintens, L. (2015). Aligning Marketing and Purchasing for new value creation. Industrial Marketing Management.

https://doi.org/10.1016/j.indmarman.2015.07.016

Maurya, U. K., Mishra, P., Anand, S., \& Kumar, N. (2015). Corporate identity, customer orientation and performance of SMEs: Exploring the linkages. IIMB Management Review, 27(3), 159-174. https://doi.org/10.1016/j.iimb.2015.05.001

Mukerjee, K., \& Shaikh, A. (2019). Impact of customer orientation on word-of-mouth and cross-buying. Marketing Intelligence \& Planning, 37(1), 97-110. https://doi.org/10.1108/MIP-01-2018-0030

Nada, N., \& Ali, Z. (2015). Service value creation capability model to assess the service innovation capability in SMEs. Procedia CIRP, 30, 390-395.

https://doi.org/10.1016/j.procir.2015.02.218

Naidoo, V. (2010). Firm survival through a crisis: The influence of market orientation, marketing innovation and business strategy. Industrial Marketing Management, 39(8), 1311-1320. https://doi.org/10.1016/j.indmarman.2010.02.005

Nasution, H. N., Mavondo, F. T., Matanda, M. J., \& Ndubisi, N. O. (2011). Entrepreneurship: Its relationship with market orientation and learning orientation and as antecedents to innovation and customer value. Industrial Marketing Management, 40(3), 336-345.

https://doi.org/10.1016/j.indmarman.2010.08.002

O’Dwyer, M., \& Gilmore, A. (2018). Value and alliance capability and the formation of strategic alliances in SMEs: The impact of customer orientation and resource optimisation. Journal of Business Research, 87, 58-68.

https://doi.org/10.1016/j.jbusres.2018.02.020

Outi, N., Dimitrios, B., \& Roger, M. (2007). Customer empowerment in tourism through consumer centric marketing (CCM). Qualitative Market Research: An International Journal, 10(3), 265-281. https://doi.org/10.1108/13522750710754308

Peterson, R. A., \& Crittenden, V. L. (2018). Exploring customer orientation as a marketing strategy of Mexican-American entrepreneurs. Journal of Business Research.

https://doi.org/10.1016/j.jbusres.2018.12.059

Racela, O. C. (2014). Customer orientation, innovation competencies, and firm performance: A proposed conceptual model. Procedia-Social and Behavioral Sciences, 148, 16-23. https://doi.org/10.1016/j.sbspro.2014.07.010

Ross, B. (2009). Ten tips to winning at consumer centricity: for retailers and manufacturers. The Journal of Consumer Marketing, 26(6), 450-454. https://doi.org/10.1108/07363760910988265

Rust, R. T., Moorman, C., \& Bhalla, G. (2010). Rethinking marketing. Harvard Business Review, 88(1/2), 94-101.

Scheinbaum, A. C., \& Wang, S. W. (2018). Customer centricity and guanxi prevalence as social capital: a study of international business relationships. Journal of Business \& Industrial Marketing, 33(8), 1209-1220.

https://doi.org/10.1108/JBIM-03-2017-0070

Shah, D., Rust, R. T., Parasuraman, A., Staelin, R., \& Day, G. S. (2006). The path to customer centricity. Journal of Service Research, 9(2), 113-124.

https://doi.org/10.1177/1094670506294666

Shelby, D. H., \& Caroline, D. (2004). The normative imperatives of business and marketing strategy: grounding strategy in resource-advantage theory. Journal of Business \& Industrial Marketing, 19(1), 5-22.

https://doi.org/10.1108/08858620410516709

Singh, R., \& Venugopal, P. (2015). The impact os salesperson customer orientation on sales performance via mediating mechanism. Journal of Business \& Industrial Marketing, 30(5), 594-607. https://doi.org/10.1108/JBIM-08-2012-0141

Smirnova, M. M., Rebiazina, V. A., \& Frösén, J. (2018). Customer orientation as a multidimensional construct: Evidence from the Russian markets. Journal of Business Research, 86, 457467. https://doi.org/10.1016/j.jbusres.2017.10.040

Sugiyarti, G., Ferdinand, A. T., \& Nurchayati, T. (2018). Acculturative products uniqueness antecedence for successful marketing performance. DLSU Business \& Economics Review, 28(1), 11.

Szymańska, E., Dziedzic, E., \& Rutkowski, A. (2017). Organisational innovations in health resort-based tourism. Business: Theory and Practice, 18(1), 54-63. https://doi.org/10.3846/btp.2017.006

Tabachnick, B. G., \& Fidell, L. S. (2012). Using multivariate statistics (6th ed.). Pearson.

Tajeddini, K. (2010). Effect of customer orientation and entrepreneurial orientation on innovativeness: Evidence from the hotel industry in Switzerland. Tourism Management, 31(2), 221-231. https://doi.org/10.1016/j.tourman.2009.02.013

Tang, T.-W., Wang, M. C.-H., \& Tang, Y.-Y. (2013). Developing service innovation capability in the hotel industry. Service Business, 9(1), 97-113. https://doi.org/10.1007/s11628-013-0220-Z

Tax, S. S., McCutcheon, D., \& Wilkinson, I. F. (2013). The service delivery network (SDN) a customer-centric perspective of the customer journey. Journal of Service Research, 16(4), 454-470. https://doi.org/10.1177/1094670513481108 
Terho, H., Eggert, A., Haas, A., \& Ulaga, W. (2015). How sales strategy translates into performance: The role of salesperson customer orientation and value-based selling. Industrial Marketing Management, 45, 12-21.

https://doi.org/10.1016/j.indmarman.2015.02.017

Ulaga, W. (2018). The journey towards customer centricity and service growth in $\mathrm{B} 2 \mathrm{~B}$ : a commentary and research directions. AMS Review, 1-4. https://doi.org/10.1007/s13162-018-0119-x

Vargo, S. L., \& Lusch, R. F. (2017). Service-dominant logic 2025. International Journal of Research in Marketing, 34(1), 46-67. https://doi.org/10.1016/j.ijresmar.2016.11.001

Vargo, S. L., Maglio, P. P., \& Akaka, M. A. (2008). On value and value co-creation: A service systems and service logic perspective. European Management Journal, 26(3), 145-152. https://doi.org/10.1016/j.emj.2008.04.003

Wang, J.-H., \& Hsu, J.-L. (2014). Effects of service innovation on oral spreading and consumption intention in catering industry. Revista de Cercetare si Interventie Sociala, 47, 220.
Wang, Q., Zhao, X., \& Voss, C. (2016). Customer orientation and innovation: A comparative study of manufacturing and service firms. International Journal of Production Economics, 171, 221-230. https://doi.org/10.1016/j.ijpe.2015.08.029

Wegner, D., Zarpelon, F. d. M., Verschoore, J. R., \& Balestrin, A. (2017). Management practices of small-firm networks and the performance of member firms. Business: Theory and Practice, 18(1), 197-207. https://doi.org/10.3846/btp.2017.021

Whelan, S., Davies, G., Walsh, M., \& Bourke, R. (2010). Public sector corporate branding and customer orientation. Journal of Business Research, 63(11), 1164-1171. https://doi.org/10.1016/j.jbusres.2009.10.013

Ziggers, G. W., \& Henseler, J. (2016). The reinforcing effect of a firm's customer orientation and supply-base orientation on performance. Industrial Marketing Management, 52, 18-26. https://doi.org/10.1016/j.indmarman.2015.07.011 